\title{
Dipping of pear fruit (Pyrus communis L.) in Calcium Chloride may help in prolonging its storability
}

\section{Zawar Hussain ${ }^{1 *}$, Mehboob Alam1, Muhammad Asif', Muhammad Azhar Shah"1, Shehnaz Khan², Jawad khan ${ }^{3}$, Islam Zeb ${ }^{1}$, Omer Mumtaz ${ }^{4}$ Ahmad Siyab ${ }^{1}$ and Arshad Jalal ${ }^{5}$}

${ }^{1}$ Department of Horticulture, The University of Agriculture Peshawar, Pakistan

${ }^{2}$ Department of Chemistry, Quaid-i-Azam University Islamabad, Pakistan

${ }^{3}$ Department of Food Science and Technology, The University of Agriculture Peshawar, Pakistan

${ }^{4}$ Department of Plant Breading and Genetics, The University of Agriculture Peshawar, Pakistan

5Department of Agronomy, The University of Agriculture Peshawar, Pakistan

*Corresponding Author: Zawar Hussain, Department of Horticulture, The University of Agriculture Peshawar,

Received: April 26, 2019; Published: July 08, 2019

DOI: 10.31080/ASAG.2019.03.0561

\begin{abstract}
An experiment was conducted at Soil Chemistry laboratory, Agriculture Research Institute Tarnab Farm Peshawar Khyber Pakhtunkhwa, during 2016 to evaluate the effect of dipping time of Calcium chloride (CaCI2) on physico-chemical properties of pear (Pyrus Communis L.) during storage. Completely Randomized Design with two factors was used. Storage durations (0, 5, 10, 15, 20, 25) days were taken as Factor $\mathrm{A}$ and dipping time in $\mathrm{CaCl} 2$ solution $(3,6$ and 9 minutes) was kept as Factor B. Quality attributes of the pear fruits were significantly affected by storage durations and dipping time. The highest ascorbic acid (6.91 mg/100 g), reducing sugar (5.77\%), TSS (16.60Brix), pH (4.8) and non-reducing sugar (4.02) and lowest percent acidity (0.03) were recorded in pear fruits dipped for 9 minutes in calcium chloride solution. In case of storage duration, highest pH of fruit juice (5.28), TSS (18.80Brix), non-reducing sugar (4.84\%) were recorded in pear fruits stored for" 25 days. More fruit percent acidity (0.06\%), lowest ascorbic acid $(5.94 \mathrm{mg} / 100 \mathrm{~g})$ and reducing sugar (5.21\%) were noted in fresh pear fruits. It was seen that pear fruits dipped for 9 minutes in CaCl2 solution maintained fruit juice $\mathrm{pH}$, ascorbic acid, percent titratable acidity, total soluble solid, reducing sugar, and non-reducing sugar. Similarly, prolonging storage duration resulted in significant increase in fruit juice $\mathrm{pH}$, total soluble solids and non-reducing sugar, while ascorbic acid content, percent titratable acidity and reducing sugar decreased with extension in storage duration from zero to twenty-five days. It was concluded from the results that pear fruits could be dipped for 9 minutes in $\mathrm{CaCl} 2$ solution for retaining quality attributes during storage.
\end{abstract}

Keywords: $\mathrm{CaCl}_{2}$; Dipping time; Pear; Physico-chemical; Storability

\section{Introduction}

Pear (Pyruscommunis L.) belongs to family Rosaceae. John Eatton Le-Conteintroduced pear to Georgia in 1856 and was named after him while its origin was Asia [1]. In Pakistan pear orchards are grows on terraces, in the hills and plan areas of Khyber Pakhtunkhwa (Hazara, Mardan and Peshawar). It is usually vegetatively propagated through cleft and whip grafting. Seeds of wild cultivar (Batang) and quince may use as universal rootstock for producing dwarf trees. Hardy, Bose, Le-Conte, Clap's Favorite, Bartlett, Samar Kandi and Kieffer are some of the important pear varieties that are grown in Pakistan [2]. Plants required calcium as it is one of its important nutrients. It is present in the middle lamella and primary cell wall in the form of pectic substances of all plant tissues.
It acts to bind cell and maintain the structure stability of cell wall during storage [3]. The gradual calcium penetration to cell wall increase the level of this ion in cell wall and thus stabilization increases, in results protection of fruits from microbial and fungal attack occurs [4]. Calcium conserve fruit qualities by preventing the fruits from physiological disorders, reduce respiration rates, pectic substances solubilization, slow down ripening processes and maintaining the firmness [5-7]. Calcium concentration in fruits peel and cortex increases by foliar application of calcium which improves shelf-life and fruit. Calcium also helps in controlling the occurrences of scald, brown core, cork spot, external and internal rots, and in enhancement of fruit color and fruit juiciness [8]. Producers and traders have to face $20-40 \%$ losses of fruits in 
Pakistan due to the mishandling, inadequate storage and/or lack of post-harvest technical knowledge/facilities that is estimated up to 3 billion rupees loss in the country [9]. Keeping in view the heavy loss of this important commodity and role of CaCl2in enhancing the post-harvest shelf life, an experiment was laid out to recognize the effect of dipping time of pear in calcium chloride and its subsequent effect on sustaining quality attributes during storage.

\section{Materials and Methods}

Experimental site and layout

The experiment was carried out at Soil Chemistry laboratory, Agriculture Research Institute (ARI) Tarnab, Peshawar during July 2016, so as to study the postharvest storage quality of pear after dipping in Calcium chloride $\left(\mathrm{CaCl}_{2}\right)$. Completely Randomized Design with two factors i.e. Dipping time in $\mathrm{CaCl}_{2}$ solution having four levels ( 0 (control), 3, 6 and 9minutes) and storage duration with six levels ( 0 (fresh fruits as a control), 5, 10, 15, 20 and 25 days) were used. These combinations were replicated three times.

\section{Fruits collection and storing}

Randomly collection of healthy pear fruits cv. Le-Conte occurred from New Developmental Farm, Horticulture, The University of Agriculture Peshawar during July 2016 at physiological maturity stage. The pear fruits were carefully brought to Soil Chemistry Laboratory, Agriculture Research Institute Tarnab Peshawar. The selected fruits were stored under ambient temperature and humidity $\left(20^{\circ} \mathrm{C}\right.$ with $\left.65-70 \% \mathrm{RH}\right)$.

\section{Studied attributes}

Data were recorded on different physico-chemical attributes of selected pear fruits.

\section{Fruit juice ph}

Fruits were randomly selected and its $\mathrm{pH}$ was determined by using $\mathrm{pH}$ meter for all treatment in each replication [10].

\section{Total soluble solids $\left({ }^{0} \mathrm{Brix}\right)$}

Some pear fruits were randomly selected and TSS were determined by refractometer.

\section{Ascorbic acid (mg/100 g)}

Ascorbic acid of randomly selected fruits from each replication was find out by using dye method as used by [11]

\section{Percent titratable acidity}

Percent titratable acidity was describe for randomly selected pear fruits in each treatment per replication by the standard method as prescribed in [12].

\section{Reducing sugar (\%)}

Hortwitz (1960) method was used for determination of Reducing sugars of juice.

\section{Non-reducing sugar $(\%)$}

Non- reducing sugar was find out by using the following formula Non-reducing sugar $=$ Total reducing sugar - free reducing sugar .

\section{Statistical Analysis:}

Statistix (8.1) was used for calculating ANOVA and LSD value. When $\mathrm{F}$ values were significant, the means comparison were done by using Least Significance Difference (LSD) test at $5 \%$ level of significance.

\section{Results and Discussion}

Fruit juice pH

Data in Table- 1 shows that the fruit juice $\mathrm{pH}$ was significantly affected by both the dipping time in $\mathrm{CaCl}_{2}$ solution and the storage duration. Maximum pH (4.8) was recorded in fruits juice, which was dipped for $9 \mathrm{~min}$ in $\mathrm{CaCl}_{2}$, while minimum $\mathrm{pH}$ (4.6) was recorded in fruit juice extracted from untreated fruits. It has also been observed that increasing storage duration can increase $\mathrm{pH}$ of fruit juice in pear. Fruit juice from fresh fruits has $\mathrm{pH}$ (4.08) and then after 25 days of storage the fruit juice $\mathrm{pH}$ increased to 5.28 .

\begin{tabular}{|l|c|c|c|}
\hline \multicolumn{1}{|c|}{ Treatments } & $\begin{array}{c}\text { Fruit } \\
\text { juice pH }\end{array}$ & $\begin{array}{c}\text { TSS } \\
\left({ }^{\mathbf{C}} \text { Brix) }\right.\end{array}$ & $\begin{array}{c}\text { Ascorbic acid } \\
\text { (mg.100g-1 }^{-1}\end{array}$ \\
\hline Dipping time (min) & & & \\
\hline 0 & $4.6 \mathrm{~b}$ & $16.1 \mathrm{c}$ & $6.66 \mathrm{~b}$ \\
\hline 3 & $4.6 \mathrm{~b}$ & $16.04 \mathrm{c}$ & $6.68 \mathrm{~b}$ \\
\hline 6 & $4.6 \mathrm{~b}$ & $16.4 \mathrm{~b}$ & $6.59 \mathrm{c}$ \\
\hline 9 & $4.8 \mathrm{a}$ & $16.6 \mathrm{a}$ & $6.91 \mathrm{a}$ \\
\hline LSD $\leq 0.05$ & 0.05 & 0.07 & 0.03 \\
\hline $\begin{array}{l}\text { Storage duration } \\
(\mathrm{days})\end{array}$ & & & \\
\hline 0 & $4.08 \mathrm{f}$ & $12.5 \mathrm{f}$ & $7.52 \mathrm{a}$ \\
\hline 5 & $4.37 \mathrm{e}$ & $15.4 \mathrm{e}$ & $7.17 \mathrm{~b}$ \\
\hline 10 & $4.58 \mathrm{~d}$ & $16.1 \mathrm{~d}$ & $6.86 \mathrm{c}$ \\
\hline 15 & $4.83 \mathrm{~d}$ & $17.0 \mathrm{c}$ & $6.58 \mathrm{~d}$ \\
\hline 20 & $5.06 \mathrm{~b}$ & $17.9 \mathrm{~b}$ & $6.20 \mathrm{e}$ \\
\hline 25 & $5.28 \mathrm{a}$ & $18.8 \mathrm{a}$ & $5.94 \mathrm{f}$ \\
\hline LSD $\leq 0.05$ & 0.04 & 0.06 & 0.04 \\
\hline
\end{tabular}

Table 1: Fruit juice pH, total soluble solid and ascorbic acid content of pear fruitas influenced by dipping time and storage duration. 
The biochemical changes in $\mathrm{pH}$ of juice occurred along with high rate of respiration and metabolic activity when fruit juice was placed in storage condition. Whenever the acidity in fruit juice decreases the $\mathrm{pH}$ will inevitably increases [13] reported that high Calcium chloride concentration can prevent a decline in fruit acidity [14] also reported similar findings that increasing storage duration can increase $\mathrm{pH}$ of apple fruit juice.

\section{Total soluble solids ( $\left.{ }^{\circ} \mathrm{brix}\right)$}

Significantly changes were recorded in total soluble solids (oBrix) of pear fruit, when $\mathrm{Ca}_{4} \mathrm{Cl}_{2}$ was dipped for different timing and the storage durations. When the fruits were allowed to dipped for 9 minutes in $\mathrm{CaCl}_{2}$, highest (16.6 ${ }^{\circ} \mathrm{Brix}$ ) was observed which was followed by ( $\left.16.4{ }^{\circ} \mathrm{Brix}\right)$ total soluble solid when the fruits was dipped for 6 minutes while minimum total soluble was recorded in untreated fruit. It has been observed that total soluble solids show increasing with time duration i.e. increasing storages time from 1 to days 25 which showed increase from 11.1 to $19.0^{\circ}$ Brix in fruit at zero to twenty-five days of storage.[15] reported that increase in TSS might be due to the changes in pectins and starches and formation of simple sugars during ripening when action of different enzymes occurred i.e. pectinase, methyl esterase and polygalaacturonase. $\mathrm{CaCl}_{2}$ can delay senescence, ripening and respiration which are responsible for increase as well as decrease of TSS and total sugars [16]. Starch present in fruits converted gradually into sugar during storage, which may result of increasing total soluble solid in untreated pear fruits. Total dissolved solids and moisture content of the fruit can aggregate and make TSS percentage. It means that application of high concentration of calcium chloride increased metabolic actions which eventually results in decreasing in apple fruits TSS [17].

\section{Ascorbic acid (mg/100g)}

Ascorbic acid of pear fruit (when dipped in $\mathrm{CaCl}_{2}$ solution) decreased along with prolonging storage period (Table 1). The lowest $(6.66 \mathrm{mg} / \mathrm{I00} \mathrm{g}$ )ascorbic acid value was detected in untreated fruits while the highest level $(6.91 \mathrm{mg} / 100 \mathrm{~g})$ of ascorbic acid was noted in $\mathrm{CaCl}_{2}$ solution when dipped for 9 minutes followed by ascorbic acid (6.59 mg/l00 g) in fruits dipped for 6 minutes in $\mathrm{CaCl}_{2}$ solution. Similarly, increasing storage duration can decreased the ascorbic acid and it was observed in fruits (7.52 to $5.94 \mathrm{mg} / 100 \mathrm{~g}$ ) during storage of 23-25 days.

When the ascorbic acid becomes matured it starts to [18] and [19]. The highest content of ascorbic acid is retained in apple fruits when treated with $\mathrm{CaCl}_{2}$. While in papaya the highest concentration of $\mathrm{CaCl}_{2}$ was recorded during storage [1]. If the temperature is high during storage condition the ascorbic acid stated to loss due to loss of antioxidant [20]. The ascorbic acid was also reduced with oxidative processes [21].

\section{Percent titratable acidity (\%)}

The dipping time of $\mathrm{CaCl}_{2}$ solution and storage durations significantly influenced the percent titratable acidity of pear fruit (Table 2). The maximum titratable acidity $(0.9 \%)$ was observed in the untreated pear fruit which was statistically at par with percent titratable acidity $(0.7 \%)$ in fruits dipped for 3 minutes in $\mathrm{CaCl}_{2}$, while the minimum titratable acidity $(0.3 \%)$ was recorded in the fruit dipped for 9 mints. Similarly, storage duration is increasing from zero to day 25 , decrease from (0.6 to $0.1 \%$ ) in percent titratable acidity [22] reported that the shelf life is increased as the fruit is decrease in acidity. The maximum titratable acidity is retained in the application of $\mathrm{CaCl}_{2}$ solution as compared to untreated apple fruit [23]. The acidity is decrease due to organic acids utilization as source of energy for the synthesis of new compounds during ripening. Also, accumulation of sugars contributes to acidity decrease [24]. The ripening process of fruit is delayed due to retention of higher values of acidity in $\mathrm{CaCl}_{2}$ treatment.

\begin{tabular}{|l|c|c|c|}
\hline Treatments & $\begin{array}{c}\text { Titratable } \\
\text { acidity (\%) }\end{array}$ & $\begin{array}{c}\text { Reducing } \\
\text { sugar (\%) }\end{array}$ & $\begin{array}{c}\text { Non-reducing } \\
\text { sugar (\%) }\end{array}$ \\
\hline $\begin{array}{l}\text { Dipping time } \\
\text { (min) }\end{array}$ & & & \\
\hline 0 & 0.09 & $4.63 \mathrm{bc}$ & $2.12 \mathrm{~d}$ \\
\hline 3 & 0.07 & $4.67 \mathrm{~b}$ & $2.29 \mathrm{c}$ \\
\hline 6 & 0.04 & $4.56 \mathrm{c}$ & $2.93 \mathrm{~b}$ \\
\hline 9 & 0.03 & $5.77 \mathrm{a}$ & $4.02 \mathrm{a}$ \\
\hline LSD $\leq 0.05$ & NS & 0.05 & 0.03 \\
\hline $\begin{array}{l}\text { Storage dura- } \\
\text { tion (days) }\end{array}$ & & & \\
\hline 0 & $0.06 \mathrm{ab}$ & $5.21 \mathrm{~b}$ & $1.22 \mathrm{f}$ \\
\hline 5 & $0.05 \mathrm{ab}$ & $5.42 \mathrm{a}$ & $1.81 \mathrm{e}$ \\
\hline 10 & $0.07 \mathrm{a}$ & $5.17 \mathrm{~b}$ & $2.29 \mathrm{~d}$ \\
\hline 15 & $0.03 \mathrm{bc}$ & $4.86 \mathrm{c}$ & $3.08 \mathrm{c}$ \\
\hline 20 & $0.02 \mathrm{c}$ & $4.50 \mathrm{~d}$ & $3.80 \mathrm{~b}$ \\
\hline 25 & $0.02 \mathrm{c}$ & $4.29 \mathrm{e}$ & $4.84 \mathrm{a}$ \\
\hline LSD $\leq 0.05$ & 0.03 & 0.07 & 0.04 \\
\hline
\end{tabular}

Table 2: Titratableacidity, reducing sugar and non-reducing sugar of pear fruit as influenced by dipping time and storage duration.

\section{Reducing sugar (\%)}

The mean value recorded showed that the pear fruits reducing sugar (\%) significantly affected by the storage duration and dipping time (Table 2). Highest percent reducing sugar (5.77\%) is noted in 
pear fruit dipped for 9 minute, followed by percent reducing sugar of fruits dipped for 6 minutes (4.56\%). Whereas minimum percent reducing sugar $(0.63 \%)$ showed in untreated fruit. Decrease in percent reducing sugar from (5.21 to 4.20\%) in freshly harvested fruit to fruit stored for 25 days.

The respiration process is delayed by the application of calcium chloride solution because the main substrate in respiration is glucose [25] which retained the percent reducing sugar. In contrast, $\mathrm{CaCl}_{2}$ treatment deactivates the activity of hydrolytic enzymes which are responsible for starch to sugars conversion. The results are in line with findings of [26] in apple.

\section{Non-reducing sugar (\%)}

It is obvious from data presented in Table 2 that there is significant influenced percent non-reducing sugar in storage durations and dipping time. Highest non-reducing sugar (4.02\%) is noted in pear dipped for 9 min in $\mathrm{CaCl}_{2}$ solution followed by non-reducing sugar (2.93) in fruits dipped for $6 \mathrm{~min}$, while lowest non-reducing sugar $(2.12 \%)$ was showed in untreated fruits. An increase in nonreducing sugar (1.22 to $4.84 \%$ ) was observed in the pear fruits from day zero to 25 day of storage.

Fruit sweetness depends upon sugar contents of apple fruit and thus is a major characteristic fruit quality. At maturation early stages starch is accumulated which is converted to sugars at edible maturity [27] and during storage [28], resulted in increased total sugar with increased storage duration [29].

\section{Conclusion}

It is concluded from the results and discussion that pear fruits dipped in $\mathrm{CaCl}_{2}$ for 9 minutes it will sustain their quality attributes for 25 days of storage and thus recommended for better quality of pear at $20^{\circ} \mathrm{C}$ with $60-70 \% \mathrm{RH}$.

\section{Authors Contributions}

Conceived and designed the experiments: Zawar Hussain, Muhammad Asif.

Performed the experiments: Muhammad Asif, Muhammad Azhar Shah.

Analyzed the data: Mehboob Alam, Omer Mumtaz, Arshad Jalal.

Contributed reagents/materials/analysis tools: Islam Zeb, Jawad Khan.

Wrote the paper: Zawar Hussain, Shehnaz Khan.

\section{Acknowledgment}

We are thankful to director of Agriculture Research Institute Tarnab, Pakistan for providing valuable facilities and kind support during experimentation.

\section{Bibliography}

1. Muhammad S. "Common fruits of Pakistan, a text book of introductory Horticulture”. Pearl paper printer (2009): 232.

2. Chaudhary MI. "A text book of horticulture by Mahmood N. Malik, Managing author Elena Bashir and Robyn Bntel, Editor. (2009): 472-474.

3. Poovaiah BW. "Molecular and cellular aspects of calcium action in plants". American Society for Horticultural Science 23.2 (1998): 267-271.

4. Poovaiah BW., et al. "Calcium and fruit softening: physiology and biochemistry". Horticultural Reviews 10 (1988): 107-152.

5. Burns J and R Pressey. "Ca2+ in cell walls of ripening tomato and peach". Journal of the American Society for Horticultural Science 112.5 (1987): 783-787.

6. Salunkhe DK and BB Desai. "Postharvest biotechnology of vegetables". 1(1984): 1-2.

7. Magee RL., et al. "Inhibiting irradiation induced softening in diced tomatoes using a calcium treatment. Session 30 G, Fruit and Vegetable Product: Processed Fruits and Vegetables. Ann. meeting and Food Expo-Anaheim, California. (2002).

8. Raese JT and SR Drake. "Effect of calcium sprays, time of harvest, cold storage, and ripeness on fruit quality of 'anjou'pears 1'. Journal of plant nutrition 23.6 (2000): 843-853.

9. Rathore HA., et al. "Effect of storage on physicochemical composition and sensory properties of mango (Mangifera indica L.) variety Dosehari”. Pakistan Journal of Nutrition 6.2 (2007): 143-148.

10. AOAC, Official method of analysis association of analytical chemistry. Washington DC. (1990).

11. AOAC, Official method of analysis association of analytical chemistry. Ed. 16th Arlington Virginia USA. (2012).

12. AOAC, Official method of analysis association of analytical chemistry. Washington DC. (1980).

13. Hayat I., et al. "Borkh". International Journal of Food Safety 5 (2005): 24-34. 
14. Khalid ZM. Studies on the extension of storage life of some important mango varieties of Punjab. (Doctoral dissertation, M. Sc. thesis of Hort. Uni. Agric. Faisalabad, Pak. (1984).

15. Hussain PR., et al. "Effect of post-harvest calcium chloride dip treatment and gamma irradiation on storage quality and shelf-life extension of Red delicious apple". Journal of Food Science and Technology 49.4 (2012): 415-426.

16. Watada AE., et al. "Factors affecting quality of fresh-cut horticultural products". Postharvest Biology and Technology 9.2 (1996): 115-125.

17. Bhartiya SP., et al. "Effect of postharvest chemical treatments on shelf life of apple (Malus domestica Borkh) fruits". The Horticulture Journal 11 (1998): 9-16.

18. Lazan HZ., et al. "Retardation of ripening and development of water stress in papaya fruit seal-packaged with polyethylene film". In Symposium on Tropical Fruit in International Trade (1989): 269.

19. Selvaraj Y., et al. "Changes in the chemical composition of four cultivars of papaya (Carica papaya L.) during growth and development". The Journal of Horticultural Science 57.1 (1982): 135-143.

20. Davey MW., et al. "Plant ascorbic acid: chemistry, function, metabolism, bioavailability and effects of processing". Journal of the Science of Food and Agriculture 80.7 (2000): 825-860.

21. Faust M and CB Shear. "The Effect of calcium on respiration of apples". Journal of the American Society for Horticultural Science 97 (1972): 437-439.

22. Wills RBH and PA Bambridge. "Use of flesh firmness and other objective tests to determine consumer acceptability of Delicious apples". Animal Production Science 20.103 (1980): 252256.

23. Drake SR and SE Spayd. "Influence of calcium treatment on 'Golden Delicious'apple quality". Journal of Food Science 48.2 (1983): 403-405.

24. Wani PA., et al. "Chromium-reducing and plant growth promoting Mesorhizobium improves chickpea growth in chromiumamendedsoil”. Biotechnology Letters 30.1 (2008): 159-163.

25. Ahdrea LBD., et al. "Post-harvest application of $\mathrm{CaCl} 2$ in strawberry fruits (Fragaria ananassa Dutch cv. Sequia) Evaluation of fruits quality and postharvest life". Cienc. AgrotecLarvars. 23 (1999): 841-848.

26. Badshah N., et al. "Role of calcium in prolonging the shelf life of apple". Sarhad Journal of Agriculture 10 (1994): 639-645.
27. Magein H and D Leurquin. "Changes in amylose, amylopectin and total starch content in jona gold apple fruit during growth and maturation". In XXV International Horticultural Congress, Part 7: Quality of Hort". Products (1998): 517.

28. Beaudry RM., et al. "Banana ripening: implications of changes in glycolytic intermediate concentrations, glycolytic and gluconeogenic carbon flux, and fructose 2,6-bisphosphate concentration". Plant physiology 91.4 (1989):1436-1444.

29. Crouch I. "Postharvest apple practices in South África". Washington tree fruit postharvest conference (2003):1-3.

Volume 3 Issue 8 August 2019

(C) All rights are reserved by Zawar Hussain., et al. 